\title{
The Saga of Leafy Spurge (Euphorbia esula) in the Northern Great Plains
}

1 eafy spurge (Euphorbia esula L.) is an invasive Eurasian perennial introduced into the United States as a contaminant of crop seed in the 1880s and 1890s. It typically forms monocultures in rangeland and natural areas of the northern Great Plains where, because of the latex that occurs in all parts of the plant, it is not consumed by naturally occurring herbivores. U.S. Geological Survey (USGS) scientists and their collaborators have been studying leafy spurge at Theodore Roosevelt National Park (TRNP) and at Arrowwood and Tewaukon National Wildlife Refuges in North Dakota since 1998. Study findings have been published in Larson and Grace (2004), Larson and others (2006), Larson and others (2007), Jordan and others (2008), and Larson and others (2008). This fact sheet summarizes that body of research.

\section{Ecological Effects}

Because leafy spurge excludes other prairie plants (Belcher and Wilson, 1989), we were interested in understanding the mechanisms that allowed its dominance. We examined both above-ground (pollination) and below-ground (plant-soil feedback) processes.

\section{Pollination}

Although invasive plants commonly compete with native plants for light and nutrients, they also may compete for pollinator services by attracting pollinators away from native flowers. On the other hand, a dense stand of flowering invasive plants may attract more pollinators to the area and, in the process, enhance pollination of neighboring natives. If insects are carrying a mixed pollen load when they visit native flowers, however, they may deposit pollen of other species, rather than the pollen necessary for native flower reproduction.

Leafy spurge provides large amounts of nectar and pollen in easily accessed flowers (cyathia) over a 4- to 6-week period in the spring, and sometimes for a shorter period in the fall at TRNP (Larson and others 2006). Its abundance is much greater than that of the native flowering plants in the vicinity of an infestation, which led us to ask if spurge had an effect on pollination of native plants. Specifically, we wondered (1) does visitation to native flowers by pollinator insects vary between infested and noninfested sites, (2) does the amount of conspecific pollen (pollen from the same species as the recipient) on stigmas vary between infested and noninfested sites, and (3) does infestation influence the number of pollen species and proportion of heterospecific pollen (pollen from different species than the recipient) on native plant stigmas?

We found that although infestation by leafy spurge had an effect on pollinator visitation, the effect was neither consistent among species nor between years (Larson and others 2006; fig. 1). Nonetheless, there were fewer conspecific pollen grains on stigmas of native species within spurge infestations, and this did not vary between the 2 years of our study. We did not find a greater number of pollen species on native stigmas within infestations, likely because species diversity was depressed in these areas (Larson and others, 2006). Further studies of how the observed conspecific pollen deficit influences seed set for native plant populations are needed before firm conclusions can be drawn about how pollinator-mediated effects of leafy spurge influence native plant populations.

\section{Plant-Soil Feedback}

Accumulating evidence suggests that substantial interactions between invasive plants and soil biota may influence the outcome of invasion events. A common way of investigating these interactions is through plantsoil feedback experiments: sterilized and live soils are conditioned by repeatedly growing either invasive or native species in them over several growth cycles. The 


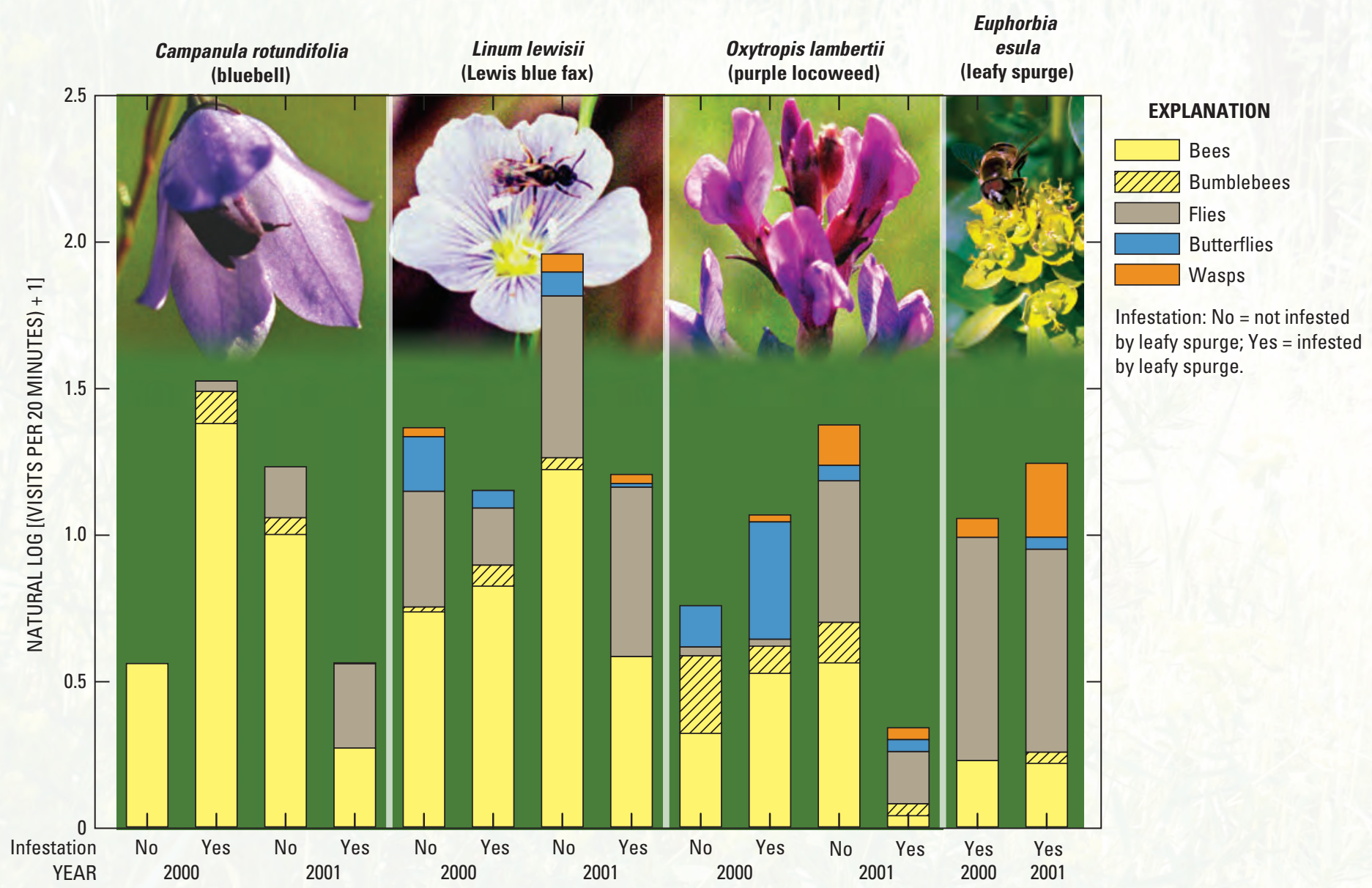

Figure 1. Visits by pollinator taxa to native plant species and leafy spurge over 2 years. Native plant species are Campanula rotundifolia, Linum lewisii, and Oxytropis lambertii.

performance of native species in the variously conditioned soils is measured. When we performed such an experiment with leafy spurge and a suite of native species common to the mixed-grass prairies of North Dakota (Jordan and others, 2008), we found that soils conditioned by leafy spurge had a negative effect on the growth of several native forb species, and further that this effect was mediated by soil biota living in unsterilized soil (fig. 2). This effect could help explain how leafy spurge becomes dominant, and may also help us develop strategic restoration plans that use species tolerant of changes in soil biota remaining even after an infestation has been controlled.

\section{Biological Control}

The biological control program for leafy spurge in the northern Great Plains is largely considered successful by land managers in the region (Hodur and others, 2006). Research by USGS scientists has demonstrated that the black flea beetles, Aphthona lacertosa/czwalinae (the two species cannot be distinguished in the field), have been effective in reducing populations of leafy spurge at TRNP (Larson and Grace, 2004) and at Arrowwood and Tewaukon National Wildlife Refuges (Larson and others, 2008). Integrated pest management, in which more than one management tool is applied in combination, also has been used in efforts to control leafy spurge. Our research indicates that if a successful biological control program has been established, addition of herbicides may produce quicker reductions in spurge populations but may also disrupt the interactions between flea beetles and leafy spurge, reducing the effectiveness of the biological control organisms (Larson and others, 2007). Herbicide effects were short lived; spurge populations 2 to 3 years after herbicide treatment were indistinguishable from those that had only biological control. Our results therefore suggest that managers consider the need for rapid control versus the potential disruption of a biological control program before deciding to use herbicides in situations where biological control is effective. 


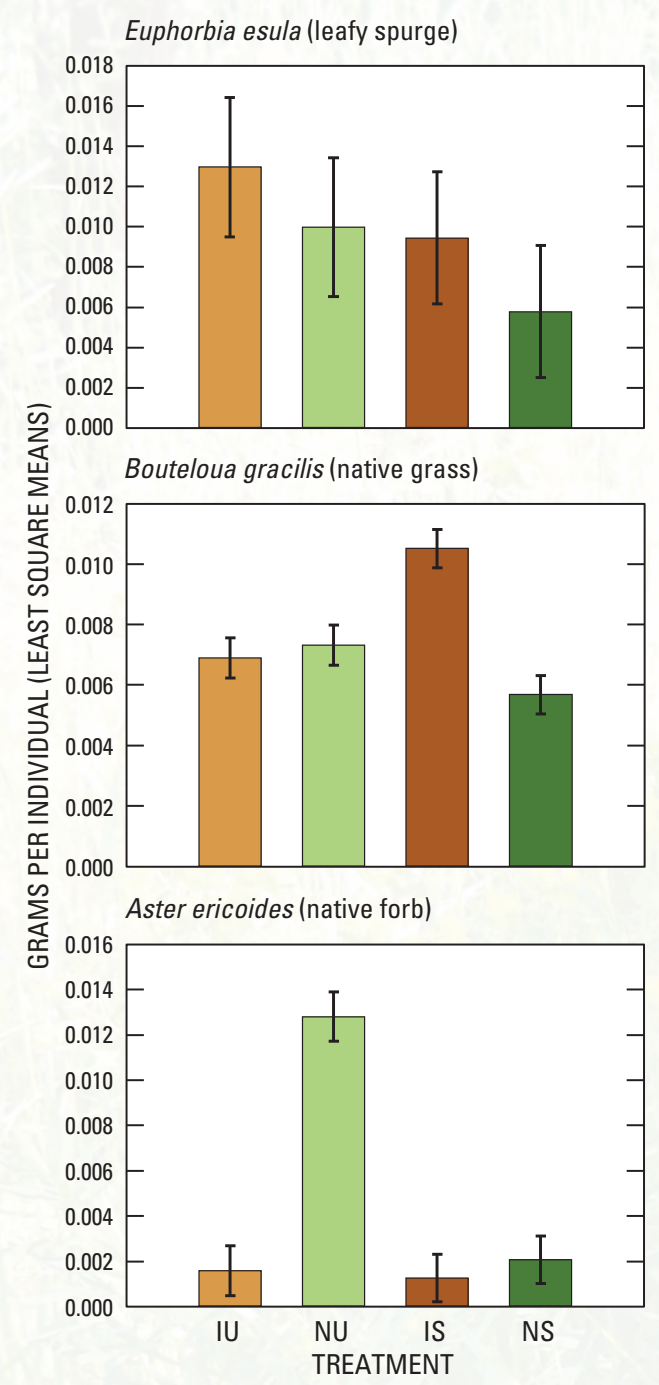

Figure 2. Seedling biomass (mass of individual seedlings in a given area) of invasive and native species in response to soil conditioning and soil sterilization treatments. Soils were collected at Theodore Roosevelt National Park and conditioned by E. esula (leafy spurge) or native species (modified from Jordan and others, 2008).
Agropyron cristatum (invasive grass)

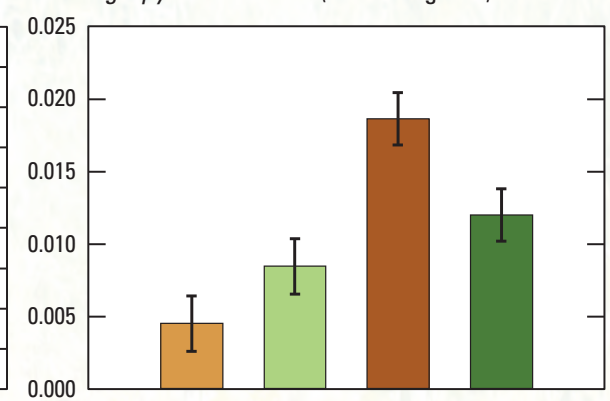

Koeleria pyramidata (native grass)

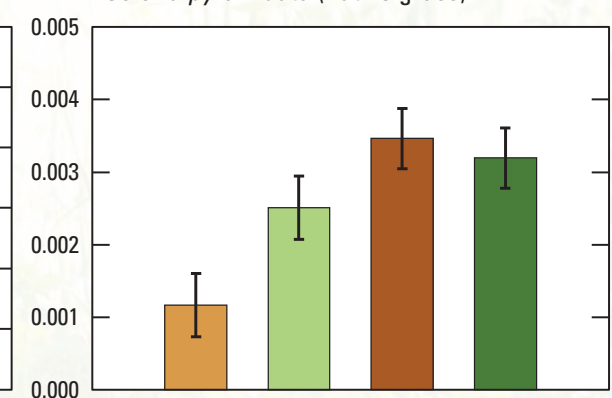

Linum lewisii (native forb)

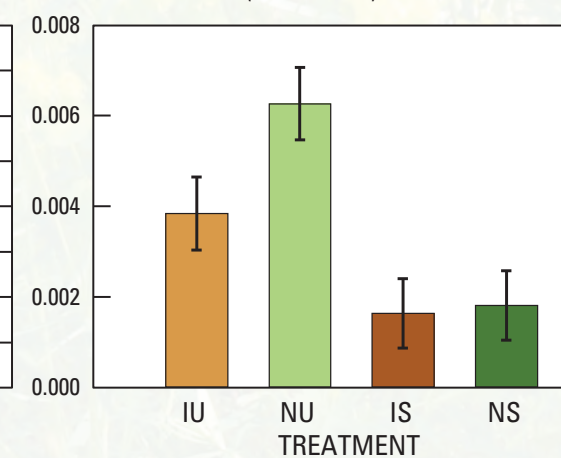

NS

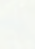

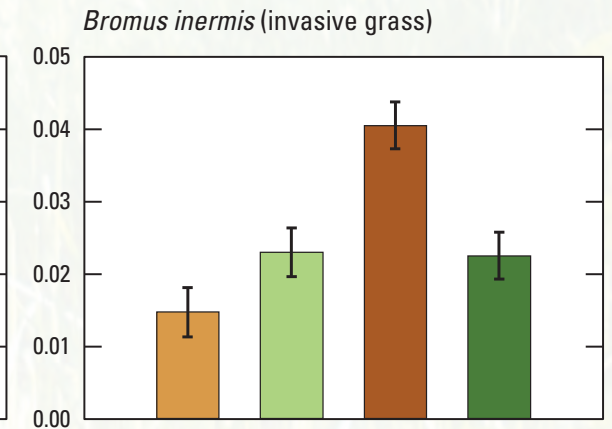

Stipa viridula (native grass)
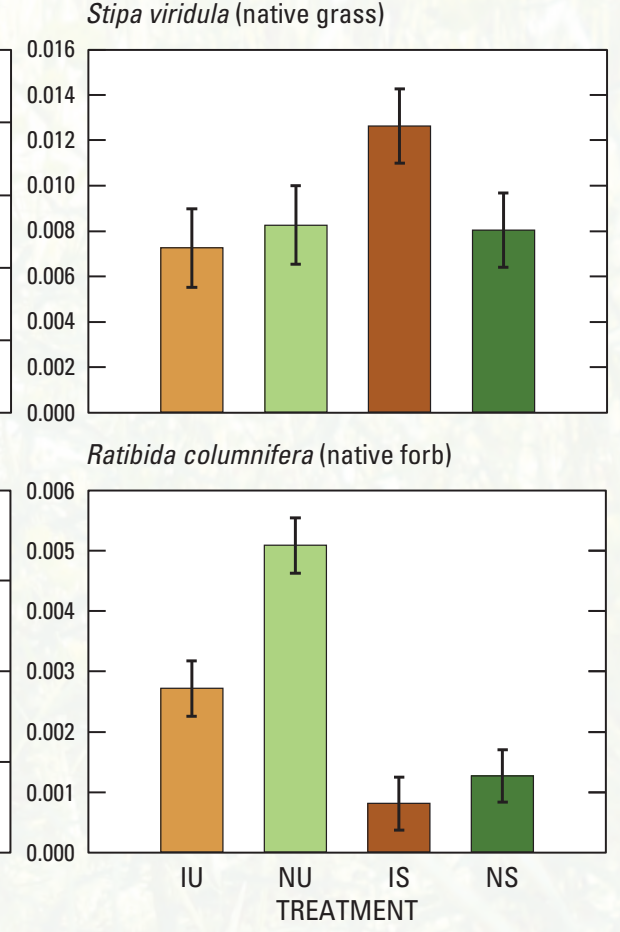

\section{EXPLANATION}

$U$ - invasive conditioning with unsterilized soil NU - native conditioning with unsterilized soil IS - invasive conditioning with sterilized soil NS - native conditioning with sterilized soil

\section{Restoration of Previously Infested Mixed- Grass Prairie}

Native prairie species do not always return after leafy spurge declines. To investigate why this occurs and to try to overcome the problem, we have identified three types of sites in the south unit of TRNP: sites that were never infested by leafy spurge, sites that were previously infested but are now dominated by native species, and sites that were previously infested but are now dominated by exotic species. Ordination (fig. 3) clearly illustrates that plots previously infested by leafy spurge but now dominated by native species are very similar to those plots that were never infested. In contrast, plots that were previously infested by leafy spurge but are now dominated by other exotic species show little overlap with never infested plots. The presence of native species in the seedbank has ruled out propagule availability as the reason for lack of native recruitment (D. Haines, unpublished data, 2009), so the question becomes, what allows native recruitment in some areas but not in others?

Our current work addresses this question in several ways: (1) we have done experimental plantings in the previously infested sites to see if differences in performance of native species we observed in the greenhouse are evident in the field; (2) collaborators in the 
Agricultural Research Service (U.S. Department of Agriculture) are assessing pathogen loads on roots of our planted species; (3) collaborators at the University of Minnesota are assessing arbuscular mycorrhizal fungi communities associated with the planted species and leafy spurge; and (4) a graduate student at the University of Minnesota is examining effects of spurge root exudates (compounds released from roots into the soil) on native prairie species germination and growth. Our goal is to provide land managers with information that will assist them in developing successful restoration strategies for these degraded sites.

\section{Partners and Collaborators}

- Paulette Scherr, U.S. Fish and Wildlife Service, Arrowwood National Wildlife Refuge

- Kristine Askerooth, U.S. Fish and Wildlife Service, Tewaukon National Wildlife Refuge

- Nick Jordan, Sheri Huerd, Jennifer Larson, and Dustin Haines, University of Minnesota

- Tony Caesar and TheCan Caesar, U.S. Department of Agriculture, Agricultural Research Service

- Paula Andersen and Laurie Richardson, National Park Service, Theodore Roosevelt National Park

- Ron Royer and Margaret Royer, Minot State University

\section{References Cited}

Belcher, J.W., and Wilson, S.D., 1989, Leafy spurge and the species composition of a mixed-grass prairie: Journal of Range Management, v. 42, no. 2, p. 172-175.

Hodur, N.M., Leistritz, F.L., and Bangsund, D.A., 2006, Biological control of leafy spurge - utilization and implementation: Rangeland Ecology \& Management, v. 59, issue 5, p. $445-452$.

Jordan, N.R., Larson, D.L., and Huerd, S.C., 2008, Soil modification by invasive plants - effects on native and invasive species of mixed-grass prairies: Biological Invasions, v. 10, no. 2 , p. $177-190$.

Larson, D.L., and Grace, J.B., 2004, Temporal dynamics of leafy spurge (Euphorbia esula) and two species of flea beetles (Aphthona spp.) used as biological control agents: Biological Control, v. 29, issue 2, p. 207-214.

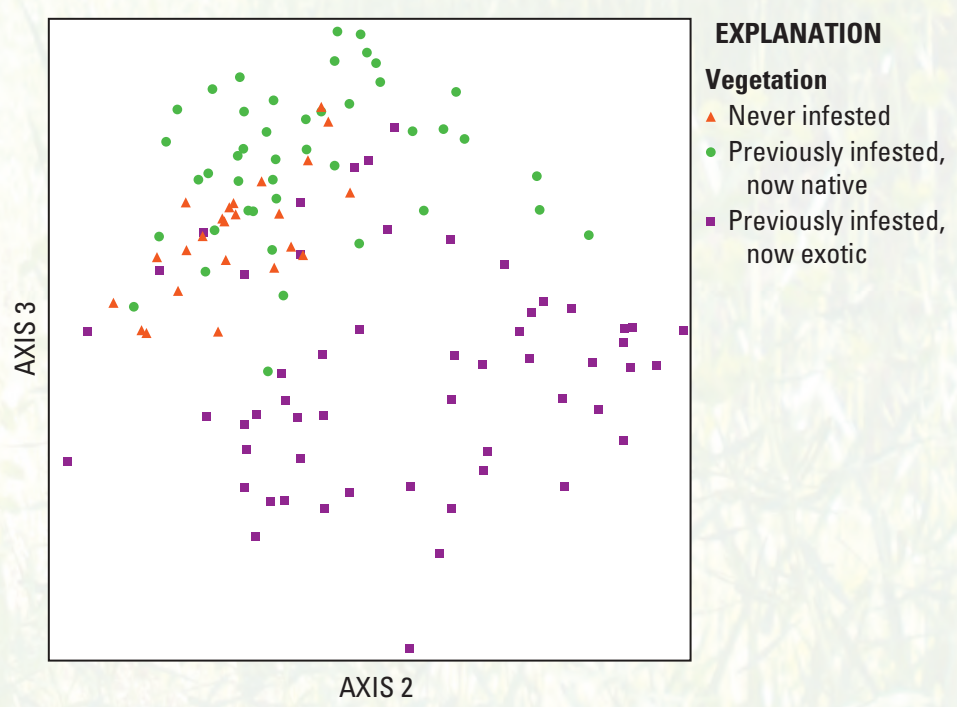

Figure 3. Ordination (by nonmetric multidimensional scaling analysis) of plots with respect to plant species cover at Theodore Roosevelt National Park. Axis 2 accounts for 37 percent and axis 3 accounts for 28 percent of the variation in the data. Vegetation on the plots was the result of natural processes; no restoration was done.

Larson, D.L., Grace, J.B., and Larson, J.L, 2008, Long-term dynamics of leafy spurge (Euphorbia esula) and its biocontrol agent, flea beetles in the genus Aphthona: Biological Control, v. 47, issue 2, p. 250-256, doi:10.1016/j.biocontrol.2008.07.016.

Larson, D.L., Grace, J.B., Rabie, P.A., and Andersen, P., 2007, Short-term disruption of a leafy spurge (Euphorbia esula) biocontrol program following herbicide application: Biological Control, v. 40, issue 1, p. 1-8.

Larson, D.L., Royer, R.A., and Royer, M.R., 2006, Insect visitation and pollen deposition in an invaded prairie plant community: Biological Conservation, v. 130, issue 1, p. 148-159.

\section{By Diane L. Larson}

\section{For more information, contact:}

\section{Director}

U.S. Geological Survey

Northern Prairie Wildlife Research Center

8711 37th Street SE, Jamestown, ND 58401

Telephone: 701-253-5500

World Wide Web: http://www.npwrc.usgs.gov 